\title{
PENGARUH KELENGKAPAN PENGISIAN FORMULIR RESUME MEDIS TERHADAP MUTU REKAM MEDIS DI RSKIA KOTA BANDUNG
}

\author{
Shofia Nurjannah Saepudin ${ }^{1}$, Irda Sari ${ }^{2}$ \\ Politeknik Piksi Ganesha Bandung, Indonesia ${ }^{1,2}$ \\ shofianurjannahsaepudin@gmail.com ${ }^{1}$, irda.sari@piksi.ac.id ${ }^{2}$
}

Received: 21-07-2021

Revised : 13-11-2021

Accepted: 18-11-2021

\begin{abstract}
Abstrak
Latar Belakang: Kelengkapan pengisian rekam medis merupakan salah satu indikator untuk mengukur mutu rekam medis,kelengkapan berkas rekam medis dapat memudahkan tenaga Kesehatan lain dalam memberikan pelayanan kepada pasien. Salah satu formulir yang berperan penting adalah resume medis, apabila pengisian resume medis tidak lengkap maka akan mempengaruhi mutu rekam medis.
\end{abstract}

Tujuan: Penelitian ini bertujuan untuk mengetahui pengaruh kelengkapan pengisian resume medis terhadap mutu rekam medis di RSKIA Kota Bandung.

Metode: Penelitian ini dilakukan pada 24 April - 26 Juni 2021. Penelitian yang digunakan penulis adalah metode kuantitatif dengan pendekatan deskriptif. Penelitian ini dilakukan dengan menyebarkan 10 kuesioner pada dokter dan Perekam Medis dan Informasi Kesehatan di RSKIA Kota Bandung. Penelitian yang digunakan penulis adalah metode kuantitatif dengan pendekatan deskriptif. dan dalam menganalisis KPLCM penulis menentukan jumlah rekapitulasi kunjungan pasien pada bulan juni 2021 sebanyak 400 dan sampel analisis KLPCM sebesar 100 pasien. Pengumpulan data dilakukan dengan cara penyebaran kuesioner, observasi dan kajian pustaka dan menggunakan uji regresi linear sederhana.

Hasil: Hasil uji hipotesis persentase penelitian menunjukkan bahwa terdapat pengaruh kelengkapan pengisian formulir resume medis terhadap mutu rekam medis di RSKIA Kota Bandung.

Kesimpulan: Penelitian ini dapat disimpulkan bahwa terdapat ketidaklengkapan pengisian rekam medis terutama pada formulir resume medis disebabkan keterbatasan dokter dalam pengisian dan Mutu Rekam Medis di RSKIA Kota Bandung masih kurang berkualitas dikarenakan kurang sosialisasi antara petugas rekam medis dengan dokter tentang pentingnya mengisi rekam medis yang lengkap.

Kata kunci: resume medis; kelengkapan resume medis; mutu rekam medis. 


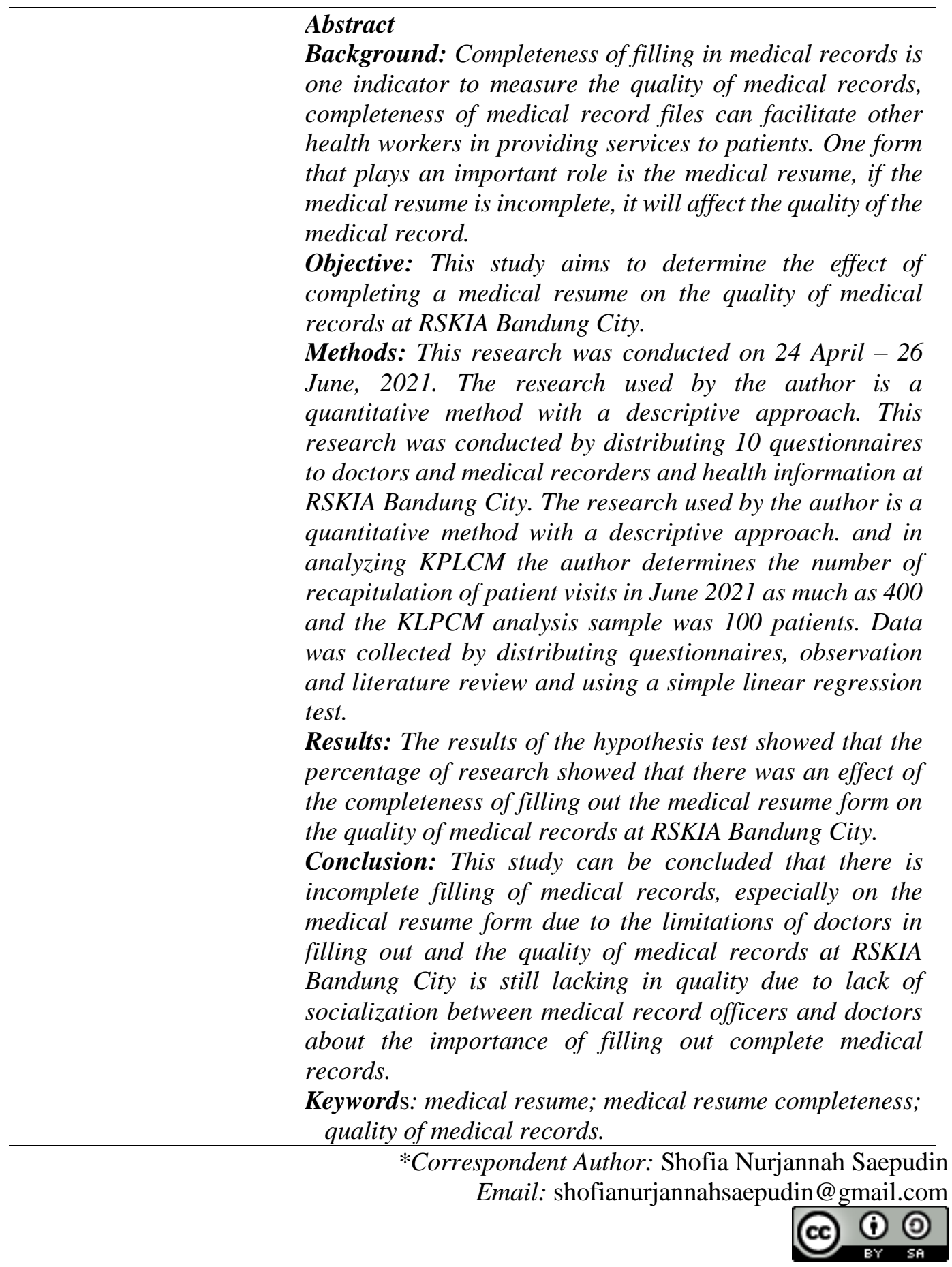

\section{PENDAHULUAN}

Pelayanan kesehatan merupakan upaya yang diselenggarakan untuk memelihara dan meningkatkan kesehatan, mencegah dan menyembuhkan penyakit serta memulihkan kesehatan perorangan, keluarga, kelompok, atau masyarakat. Salah satu yang menjadi rujukan tempat pelayanan kesehatan terbesar dan terlengkap saat ini adalah rumah sakit (Sandra \& Witcahyo, 2017).

Salah satu Institusi pelayanan masyarakat dalam bidang kesehatan yaitu rumah sakit. Tugas dan fungsi di Rumah Sakit berhubungan dengan kelas A, B, C, dan D. Salah Pengaruh Kelengkapan Pengisian Formulir Resume Medis Terhadap Mutu Rekam Medis di RSKIA Kota Bandung 
satu keberhasilan sebuah rumah sakit adalah sistem penyelenggaraan rekam medis yang merupakan berkas berisi catatan dan dokumen mengenai identitas pasien, hasil pemeriksaan, pengobatan, tindakan, dan pelayanan lainnya yang diterima pasien pada sarana kesehatan, rumah sakit memiliki beberapa jenis pelayanan antara lain: pelayanan rawat jalan, pelayanan rawat inap, pelayanan gawat darurat serta pelayanan terkait lainnya yang mendukung terpenuhi pelayanan kesehatan dan diantaranya adalah unit rekam medis (Nuraini, 2015).

Rekam medis adalah berkas yang berisikan catatan identitas pasien, pemeriksaan, pengobatan, tindakan dan pelayanan lain yang telah diberikan kepada pasien (Ordila, 2020). Pada pengelolaan rekam medis harus sesuai dengan standar prosedur operasional yang telah ditetapkan rumah sakit tersebut, yaitu dengan cepat, tepat, akurat, lengkap dan berisikan fakta yang sebenar-benarnya sehingga dapat meningkatkan mutu medis serta efisiensi dalam pelayanan kesehatan di rumah sakit yang didukung oleh petugas berkompeten dan paham di bidang rekam medis (Sukma \& Siswati, 2017).

Rekam Medis tidak hanya sekedar kegiatan pencatatan, akan tetapi mempunyai pengertian sebagai suatu sistem penyelenggaraan rekam medis, kegiatan rekam medis yaitu mulai pencatatan selama pasien mendapatkan pelayanan medis, penanganan berkas rekam medis yang meliputi penyimpanan serta pengeluaran berkas dari tempat penyimpanan untuk melayani permintaan/peminjaman untuk keperluan lainnya (Handiwidjojo, 2015).

Ketidaklengkapan pengisian rekam medis sangat berpengaruh terhadap mutu rekam medis, karena mutu rekam medis merupakan cermin baik tidaknya mutu rekam medis, sehingga apabila rekam medis tidak lengkap dapat mempengaruhi kualitas mutu rekam medis. maka hal ini menjadi tuntutan bagi seluruh praktisi sarana pelaksanaan kesehatan dalam penyelenggaraan rekam medis yang bermutu, diantaranya yaitu dengan pengisian formulir resume medis yang lengkap dan tepat (Mangentang, 2018).

Resume medis dibuat sebagai ringkasan pelayanan yang diberikan oleh tenaga kesehatan, khususnya dokter, selama masa perawatan hingga pasien keluar baik dalam keadaan hidup maupun meninggal (Erliza, 2021). Resume medis harus diisi lengkap dan dibuat dengan singkat disertai nama dan tandatangan dokter yang merawat pasien, serta harus dapat menjelaskan informasi penting mengenai penyakit, pemeriksaan yang dilakukan selama perawatan, dan pengobatan yang didapat terhadap pasien (Hidayati \& Dewi, 2018), Dokter bertanggung jawab dalam mengisi dokumen rekam medis, terutama pada formulir resume medis.

penelitian ini bertujuan untuk mengetahui pengaruh kelengkapan pengisian formulir resume medis terhadap mutu rekam medis di RSKIA Kota Bandung, Berdasarkan pengalaman praktik kerja lapangan (PKL) di RSKIA Kota Bandung pada 26 April - 26 Juni 2021 ditemukan ketidaklengkapan pengisian rekam medis terutama pada formulir resume medis dan Mutu Rekam Medis di RSKIA Kota Bandung masih kurang berkualitas maka diharapkan hasil penelitian ini dapat menjadi bahan pertimbangan untuk evaluasi mutu rekam medis di seluruh rumah sakit di Indonesia khususnya di RSKIA Kota Bandung agar mutu rekam medis dapat berkualitas dengan baik.

\section{METODE PENELITIAN}

Metode penelitian yang digunakan pada penelitian ini adalah metode kuantitatif dengan pendekatan deskriptif, Menurut (Sugiyono, 2009) Menjelaskan bahwa metode kuantitatif merupakan metode penelitian yang berbasis pada filsafat positivisme, yang mana digunakan untuk meneliti populasi atau sampel tertentu, yang umumnya pengambilan sampelnya dilakukan secara random dan data dikumpulkan menggunakan instrumen penelitian, lalu dianalisis secara kuantitatif/statistic dengan tujuan menguji hipotesis yang telah ditetapkan. Menurut (Narbuko, 2015) penelitian deskriptif adalah penelitian yang 
berusaha untuk menuturkan pemecahan masalah yang ada sekarang berdasarkan data-data, dengan menyajikan, menganalisis dan menginterpretasikannya.

Menurut (Choyrina et al., 2018), populasi adalah keseluruhan objek penelitian. Apabila seseorang ingin meneliti semua elemen yang ada dalam wilayah penelitian, maka penelitiannya merupakan penelitian populasi atau studi populasi atau studi sensus. Populasi dalam penelitian ini adalah Dokter dan petugas rekam di RSKIA Kota Bandung dan sampel penelitian ini yaitu 10 dokter dan perekam medis dan informasi Kesehatan, Teknik pengumpulan data dilakukan dengan cara penyebaran kuesioner, observasi dan kajian Pustaka.

Instrumen penelitian ini dengan menggunakan kuesioner. Kuesioner merupakan Teknik pengumpulan data yang dilakukan dengan cara memberi seperangkat pertanyaan atau pernyataan secara tertulis kepada responden untuk jawabnya. (Sugiyono, 2007) maka peneliti dapat memperoleh informasi mengenai pengaruh kelengkapan pengisian formulir resume medis terhadap mutu rekam medis di RSKIA Kota Bandung, Setelah pengumpulan data selesai maka hasil pengumpulan data diolah dengan menggunakan perangkat lunak IBM SPSS Statistik.

\section{HASIL DAN PEMBAHASAN}

\section{A. Hasil Penelitian}

Berdasarkan hasil penelitian dan data yang diperoleh penulis berjudul "Pengaruh Kelengkapan Pengisian resume Medis Terhadap Mutu Rekam Medis di RSKIA Kota Bandung" Berikut gambaran indikator mutu rekam medis yang diteliti di RSKIA Kota Bandung, maka syarat rekam medis yang bermutu yaitu:

1. Lengkap

Berdasarkan hasil penelitian yang dilakukan penulis di RSKIA Kota bandung dari 400 populasi dan 100 sampel pada bulan juni terdapat $85 \%$ rekam medis yang tidak lengkap khususnya pada formulir resume medis. Hal ini disebabkan karena keterbatasan waktu dalam mengisi rekam medis, sehingga mengakibatkan penurunan mutu rekam medis.

2. Akurat

Berdasarkan hasil penelitian pada Pengisian rekam medis di RSKIA kota Bandung sudah sesuai dengan fakta yang ada, bahwa pengisian rekam medis diisi oleh petugas yang memberikan pelayanan pada pasien. Semua dokter diwajibkan untuk mengisi rekam medis terutama pada formulir resume medis, tetapi masih ada $85 \%$ yang tidak lengkap, salah satunya disebabkan karena keterbatasan waktu seorang dokter sehingga menyebabkan keterlambatan dalam kelengkapan pengisian resume medis.

3. Tepat Waktu

Pengembalian berkas rekam medis di RSKIA Kota Bandung sudah sesuai standar PERMENKES No.269/MENKES/PER/III/2008, yaitu Rekam medis harus dikembalikan paling lambat 2 × 24 jam setiap pasien pulang (Permenkes, 2008).

4. Memenuhi aspek hukum

Dari 100 sampel berkas rekam medis pada formulir resume medis rawat inap yang diteliti terdapat $85 \%$ berkas formulir resume medis yang tidak ditandatangani oleh dokter. Maka hal ini dapat menyebabkan penurunan mutu rekam medis, dan bisa mengakibatkan kerugian bagi pihak rumah sakit. Pada item tersebut sangat penting bagi rumah sakit karena dapat dijadikan alat bukti dalam pengadilan apabila terjadi hal - hal yang merugikan salah satu pihak. 
Hasil Pengujian Analisis Data

1. Uji Validasi

Uji validitas digunakan peneliti untuk mengukur sejauh mana kevalidan suatu kuesioner, apabila nilai $r$ hitung > nilai $r$ tabel maka kuesioner dapat dianggap valid, penulis melakukan uji validasi berdasarkan hasil pengolahan dengan menggunakan spss sebagai berikut:

Tabel 1 Uji Validasi

\begin{tabular}{ccc}
\hline Nilai $\mathbf{r}$ hitung & Nilai $\mathbf{r}$ tabel & Hasil Uji Validasi \\
\hline 0,952 & 1,859 & Valid \\
\hline 0,848 & 1,859 & Valid \\
\hline 0,848 & 1,859 & Valid \\
\hline 0,745 & 1,859 & Valid \\
\hline
\end{tabular}

Sumber: Diolah Oleh Penulis ( SPSS )

Berdasarkan tabel 1 diatas dapat ditarik kesimpulan menunjukan bahwa $\mathrm{r}$ hitung >nilai $r$ tabel, maka butir setiap pernyataan dalam kuesioner dapat dinyatakan valid.

2. Uji Reliabilitas

Uji Reliabilitas digunakan penulis untuk mengukur konsistensi pada kuesioner setelah dilakukan berulang - ulang, kuesioner dianggap reliabel jika nilai koefisien reliabilitas atau cronbach alpha $>0,60$.

Tabel 2. Uji Reliabilitas

\begin{tabular}{lc}
\hline Reliability Statistics & \\
\hline Cronbach's Alpha & N of Items \\
\hline .785 & 4 \\
\hline Sumber: Diolah Oleh Penulis ( SPSS )
\end{tabular}

Berdasarkan hasil uji reliabilitas tabel 2 di atas menunjukkan bahwa nilai koefisien reliabilitas atau cronbach alpha $>0,60$ dengan jumlah $\mathrm{N}$ of item atau butir pernyataan kuesioner sebanyak 4 dan nilai cronbach alpha sebesar 0,785 , maka dapat dinyatakan bahwa kuesioner reliabel atau konsisten.

3. Uji Regresi Linear Sederhana

Uji regresi linear sederhana yaitu menguji antara pengaruh tidaknya antara variabel $\mathrm{x}$ atau kelengkapan resume medis terhadap variabel $\mathrm{Y}$ atau mutu rekam medis.

Tabel 3.Uji Regresi Linear Sederhana

\begin{tabular}{|c|c|c|c|c|}
\hline & \multicolumn{4}{|c|}{ Coefficients ${ }^{a}$} \\
\hline & $\begin{array}{l}\text { Unstandardized } \\
\text { Coefficients }\end{array}$ & $\begin{array}{l}\text { Standardized } \\
\text { Coefficients }\end{array}$ & & \\
\hline Model & Std. Error & Beta & $\mathbf{T}$ & Sig. \\
\hline (Constant) & 3.894 & & 2.361 & .046 \\
\hline $\begin{array}{l}\text { kelengkapan Formulir } \\
\text { Resume Medis }\end{array}$ & 519 & 663 & 2.505 & .037 \\
\hline
\end{tabular}

a. Dependent Variable: Mutu Rekam Medis

Sumber: Diolah Oleh Penulis ( SPSS )

Pengaruh Kelengkapan Pengisian Formulir Resume Medis Terhadap Mutu Rekam Medis di RSKIA Kota Bandung 
Berdasarkan kesimpulan pada tabel 3 di atas mengenai hasil uji regresi linear sederhana menunjukan nilai konstanta (a) sebesar 9, 194 dan nilai kelengkapan formulir resume medis (b) sebesar 0,519 jadi rumus persamaan regresi dari hasil tersebut adalah $\mathrm{Y}$ $=9,194+0,519$, maka dalam setiap penambahan $1 \%$ nilai kelengkapan formulir resume medis maka nilai mutu rekam medis bertambah sebesar 0,519 , nilai koefisien regresi bernilai positif sehingga dapat dikatakan bahwa arah pengaruh variabel $\mathrm{x}$ dan $\mathrm{y}$ adalah positif.

4. Uji Hipotesis Terhadap Korelasi (Uji T Hipotesis)

Uji Hipotesis digunakan untuk menguji suatu pernyataan dengan menggunakan metode statistik (Suparman, 2020).

$\mathrm{HO}$ : kelengkapan formulir resume medis rawat inap tidak berpengaruh terhadap mutu rekam medis di RSKIA Kota Bandung.

$\mathrm{H} 1$ : Kelengkapan formulir resume medis rawat inap berpengaruh terhadap mutu rekam medis di RSKIA Kota Bandung.

Tabel 4. Uji Hipotesis Terhadap Korelasi ( Uji T Hipotesis )

Nilai t hitung Nilai t tabel

$\frac{2,5052,306}{\text { Sumber : Diolah Oleh Penulis (SPSS) }}$

Berdasarkan tabel 4 di atas hasil uji hipotesis menggunakan t hitung 2, 505 dengan nilai $t$ tabel sebesar 2, 306. Hipotesis penelitian (H1) dapat diterima dan Hipotesis alternatife $(\mathrm{H} 0)$ ditolak apabila nilai $\mathrm{t}$ hitung $>\mathrm{t}$ tabel. Berdasarkan hasil pengujian di atas maka pernyataan hipotesis penelitian (H1) bahwa kelengkapan pengisian resume medis rawat inap berpengaruh terhadap mutu rekam medis di RSKIA Kota Bandung dapat diterima, karena nilai $\mathrm{t}$ hitung sebesar 2, $505>$ nilai $\mathrm{t}$ tabel sebesar 2, 306 .

5. Uji Koefisien Determinan $\left(\mathrm{R}^{2}\right)$

Uji koefisiensi determinan yaitu seberapa besar pengaruh dari variabel kelengkapan formulir resume medis terhadap mutu rekam medis. Berikut adalah hasil koefisien determinasi pada hasil uji diatas dengan spss dalam uji regresi linear sederhana.

Tabel 5.Uji Koefisiensi Determinan ( $\left.\mathbf{R}^{2}\right)$ Model Summary

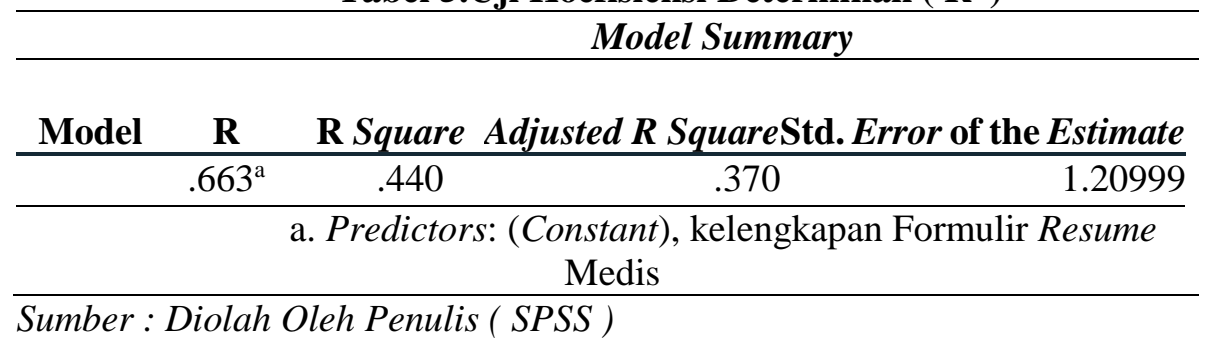

Berdasarkan tabel 5 di atas, maka hasilnya menunjukan nilai $\mathrm{R}^{2}$ pada kolom $\mathrm{R}$ Square sebesar 0, 440 yang berarti bahwa pengaruh kelengkapan pengisian resume medis rawat inap terhadap mutu rekam medis di RSKIA Kota Bandung sebesar $44 \%$ sedangkan sisanya sebesar $56 \%$ dipengaruhi oleh variabel lain atau error. 


\section{B. Pembahasan}

\section{Permasalahan Yang Timbul Mengenai Pengaruh Kelengkapan Pengisian Formulir} Resume Medis Rawat Inap Terhadap Mutu Rekam Medis di RSKIA Kota Bandung. Berdasarkan hasil penelitian yang dilakukan oleh penulis di RSKIA Kota Bandung, peneliti menemukan permasalahan mengenai kelengkapan pengisian resume medis rawat inap di RSKIA Kota Bandung terhadap mutu rekam medis, adapun permasalahan tersebut yaitu sebagai berikut :

1. Terdapat ketidaklengkapan pengisian rekam medis terutama pada formulir resume medis disebabkan keterbatasan waktu dokter dalam pengisian.

2. Mutu rekam medis di RSKIA Kota Bandung masih kurang berkualitas dikarenakan kurang sosialisasi antara petugas rekam medis dengan dokter tentang pentingnya mengisi rekam medis dengan lengkap.

\section{Upaya Pemecahan Permasalahan Pengaruh Kelengkapan Pengisian Resume Medis Terhadap Mutu Rekam Medis di RSKIA Kota Bandung.}

Berdasarkan permasalahan diatas berikut upaya pemecahan permasalah pengaruh

Kelengkapan pengisian resume medis terhadap mutu rekam medis di RSKIA Kota Bandung.

1. Mengadakan evaluasi dan sosialisasi secara rutin tentang pentingnya pengisian rekam medis agar sesuai dengan Standar Operasional Prosedur (SOP) kepada tenaga kesehatan yang bertanggung jawab. Menurut Assesment dalam pedoman penyelenggaraan rekam medis, program kerja akreditasi rumah sakit atau puskesmas mewajibkan pemberlakuan SOP (Standar Operasional Prosedur) harus diperbaharui melalui penetapan tertulis direktur rumah sakit atau kepala puskesmas.Maka hal ini diharapkan dapat meningkatkan Mutu Rekam Medis di RSKIA Kota Bandung .

2. Mengadakan pelatihan kepada karyawan tentang pengisian dokumen rekam medis terutama pada formulir resume medis maka hal ini diharapkan dapat meningkatkan kualitas mutu rekam medis di RSKIA Kota Bandung.

Menurut (Training et al., 2020) Pelatihan merupakan serangkaian aktivitas individu dalam meningkatkan keahlian dan pengetahuan secara sistematis sehingga mampu memiliki kinerja yang profesional di bidangnya.Pelatihan adalah proses pembelajaran yang memungkinkan pegawai melaksanakan pekerjaan sesuai dengan standar.

\section{KESIMPULAN}

Berdasarkan hasil penelitian yang dilakukan penulis di RSKIA Kota Bandung pada 26 April - 26 Juni 2021, maka dapat diambil kesimpulan mengenai kelengkapan pengisian resume medis rawat rawat inap di RSKIA Kota Bandung sudah sesuai dengan mekanisme dan teknis yang ditetapkan hanya pelaksanaanya belum optimal, karena berdasarkan penelitian yang dilakukan penulis masih terdapat rekam medis pada formulir resume medis yang tidak lengkap pada saat assembling.

Berdasarkan hasil pengujian yang dilakukan oleh penulis menggunakan kuesioner, maka hasil yang diperoleh peneliti dengan menggunakan model uji regresi linear sederhana, dengan banyaknya sampel $\mathrm{N}=10$ dan tingkat kepercayaan $95 \%$ diperoleh Hasil t hitung $=2,505$ (dapat dilihat dari tabel coefficients) dari variabel kelengkapan formulir resume medis rawat inap $(\mathrm{X})$ terhadap mutu rekam medis $(\mathrm{Y})$ dan t tabel sebesar 2, 306 sehingga thitung $>\mathrm{t}$ tabel, maka $\mathrm{H} 0$ ditolak dan $\mathrm{H} 1$ diterima, maka kelengkapan pengisian resume medis rawat inap berpengaruh terhadap mutu rekam medis di RSKIA Kota Bandung. Pengaruhnya sebesar $44 \%$ pengaruh dari variabel kelengkapan formulir resume 
medis terhadap mutu rekam medis sedangkan sisanya 56\% dipengaruhi variabel lain atau error (e).

\section{BIBLIOGRAFI}

Erliza, R. N. (2021). Aplikasi Pencatatan Resume Medis di Rumah Sakit Umum. Administration \& Health Information Of Journal, 2(2), 274-280.

Handiwidjojo, W. (2015). Rekam medis elektronik. Jurnal Eksplorasi Karya Sistem Informasi Dan Sains, 2(1).

Hidayati, M., \& Dewi, R. M. (2018). Pengaruh Kelengkapan Formulir Resume Medis Rawat Inap Terhadap Mutu Rekam Medis Di Rsud Kabupaten Sumedang. Jurnal INFOKES (Informasi Kesehatan), 2(2), 72-82.

Mangentang, F. R. (2018). Kelengkapan Resume Medis dan Kesesuaian Penulisan Diagnosis Berdasarkan ICD-10 Sebelum dan Sesudah JKN di RSU Bahteramas. Jurnal Administrasi Rumah Sakit Indonesia, 1(3). http://dx.doi.org/10.7454/arsi.v1i3.2181

Narbuko, C. (2015). Abu achmadi. Metodologi Penelitian.

Nuraini, N. (2015). Analisis Sistem Penyelenggaraan Rekam Medis di Instalasi Rekam Medis RS “ X” Tangerang Periode April-Mei 2015. Jurnal Administrasi Rumah Sakit, 1(2), 147-158. http://dx.doi.org/10.7454/arsi.v1i3.2180

Ordila, R., Wahyuni, R., Irawan, Y., \& Sari, M. Y. (2020). Penerapan Data Mining Untuk Pengelompokan Data Rekam Medis Pasien Berdasarkan Jenis Penyakit Dengan Algoritma Clustering (Studi Kasus: Poli Klinik Pt. Inecda). Jurnal Ilmu Komputer, 9(2), 148-153. https://doi.org/10.33060/JIK/2020/Vol9.Iss2.181

Permenkes, R. I. (2008). Permenkes Nomor 269/Menkes/Per/III/2008 Tentang Rekam Medis. Jakarta: Kemenkes RI.

Sandra, M., \& Witcahyo, E. (2017). Perbedaan kepuasan antara pasien peserta jaminan kesehatan nasional dengan umum berdasarkan mutu pelayanan kesehatan di instalasi rawat inap rsd dr. Soebandi jember.

Sugiyono. (2007). Statistika untuk penelitian. Alfabeta.

Sugiyono, M. P. P., \& Kuantitatif, P. (2009). Kualitatif, dan R\&D, Bandung: Alfabeta. Cet. Vii.

Sukma, R. S., \& Siswati, S. (2017). Tinjauan Pelaksanaan Standar Prosedur Operasional Distribusi Rekam Medis Rawat Jalan di Rumah Sakit Umum Daerah Kota Bekasi. Indonesian of Health Information Management Journal (INOHIM), 5(2), 125-129. https://doi.org/10.47007/inohim.v5i2.138

Suparman, S. E. (2020). Menguji Hipotesis.

(C) 2021 by the authors. Submitted for possible open access publication under the terms and

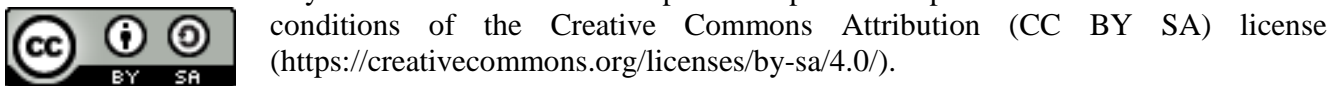

Pengaruh Kelengkapan Pengisian Formulir Resume Medis Terhadap Mutu Rekam Medis di RSKIA Kota Bandung 